Ege Tıp Dergisi / Ege Journal of Medicine 2020; 59 (2): 133-135

\title{
Pemfigus vulgariste çivi belirtisi: Bir olgu sunumu
}

\section{Tin tack sign in pemphigus vulgaris: A case report}

\author{
Ayda Acar ${ }^{1}$ Funda Kuşcu Akdeniz ${ }^{1}$ Taner Akalın ${ }^{2}$ Is Iş Karaarslan $^{1}$ (D) \\ ${ }^{1}$ Ege Üniversitesi, Tıp Fakültesi, Dahili Tıp Bilimleri Bölümü, Dermatoloji Anabilim Dalı, İzmir, Türkiye \\ ${ }^{2}$ Ege Üniversitesi, Tıp Fakültesi, Cerrahi Tıp Bilimleri Bölümü, Tıbbi Patoloji Anabilim Dalı, İzmir, Türkiye
}

Öz

Çivi belirtisi, bir lezyondan kaldırılan krut ve skuamın alt yüzeyinde boynuzsu ve dikensi çıkıntıların varlığı olarak tanımlanmaktadır. Illk defa ünlü Türk dermatolog Prof. Dr. Hulusi Behçet tarafından kutanöz layşmanyaziste tanımlanmıştır. Literatürde kutanöz layşmanyazis dışında diskoid lupus eritematozus, pemfigus foliaseus, liken planus, seboreik dermatit, radyoterapi sonrası skalpte gelişen skuamlar ve kutanöz B hücreli lenfoma olgularında da bildirilmiştir.

Burada 68 yaşında erkek hastanın gövde yerleşimli bir pemfigus vulgaris lezyonunda görülen çivi belirtisi, pemfigus vulgariste daha önce çivi belirtisinin tanımlanmamış olması ve ülkemiz dermatologlarının çok iyi bildiği çivi belirtisinin belirgin krut ve skuam ile seyreden pemfigus vulgaris lezyonlarında da görülebileceğinin hatırlatılması amacıyla sunulmaktadır.

Anahtar Sözcükler: Çivi belirtisi, pemfigus vulgaris, Hulusi Behçet.

\begin{abstract}
The tin tack sign is defined as the presence of thorn-like protrusions on the lower surface of the crust or squam removed from a lesion. Famous Turkish Dermatologist Prof. Dr. Hulusi Behçet described tintack sign in cutaneous leishmaniasis for the first time. This sign is also reported in discoid lupus erythematosus, pemphigus foliaseus, lichen planus, seborrheic dermatitis, scalp squams developing after radiotherapy and cutaneous B cell lymphoma in the literature except cutaneous leishmaniasis.

Here, we present a 68-year-old man with tin tack sign seen in a pemphigus vulgaris lesion located on the trunk because tin tack sign was not reported in pemphigus vulgaris yet and to remind Turkish dermatologists who are well informed about this sign, tin tack sign can also be seen in pemphigus vulgaris.
\end{abstract}

Keywords: Tin tack sign, pemphigus vulgaris, Hulusi Behçet.

\section{Giriş:}

Çivi belirtisi, bir lezyondan kaldırılan krut ve skuamın alt yüzeyinde boynuzsu ve dikensi çıkıntıların varı̆̆ı olarak tanımlanmaktadır. İlk defa ünlü Türk dermatolog Prof. Dr. Hulusi Behçet tarafından kutanöz layşmanyaziste $(\mathrm{KL})$ tanımlanmıştır $(1,2)$.

Literatürde $\mathrm{KL}$ dışında diskoid lupus eritematozus (DLE), pemfigus foliaseus (PF) (3), ilaç ile indüklenmiş liken planus (4), seboreik dermatit (5), radyoterapi sonrası skalpte gelişen skuamlar

\footnotetext{
Sorumlu yazar: Ayda Acar

Ege Üniversitesi, Tıp Fakültesi, Dahili Tıp Bilimleri Bölümü, Dermatoloji Anabilim Dalı, İzmir, Türkiye

E-posta: aydaerbas@yahoo.com

Başvuru tarihi: 26.06.2019 Kabul tarihi: 25.11.2019
}

(6) ve kutanöz $B$ hücreli lenfoma $(\mathrm{KBHL})(7)$ olgularında da bildirilmiştir.

Çivi belirtisinde görülen çıkıntıların histopatolojik karşıığı folliküler keratin tıkaçlardır ve bu çıkıntıların dermal ödem olan lezyonlarda krutun kaldırıması esnasında keratin tıkaçların kendini çevreleyen epidermisten kolayca ayrılması ile oluştuğu düşünülmektedir (6).

Burada gövde yerleşimli bir pemfigus vulgaris (PV) lezyonunda görülen çivi belirtisi PV'de daha önce çivi belirtisinin tanımlanmamış olması nedeniyle sunulmaktadır. 


\section{Olgu Sunumu:}

Altmış sekiz yaşında erkek hasta yüzünde ve sırtında çıkan yaralar nedeniyle başvurdu. Öyküsünden 2010 yılından itibaren PV tanısıyla takip edilmekte olduğu, metilprednizolon 8 $\mathrm{mg} /$ gün ve azatiyopirin $100 \mathrm{mg} / \mathrm{gün}$ tedavisi altındayken son 2 haftadır yeni lezyon çıkışları olduğu öğrenildi. Özgeçmişinde 30 paket/yıl sigara kullanımı, kolesistektomi ve subtotal tirodektomi öyküsü mevcuttu. Soy geçmişinde özellik yoktu. Dermatolojik muayenesinde sağ frontal bölgede erode alanlar, sırtta yüzeyi krutlanmış bir adet lezyon mevcuttu. Sırtta bulunan lezyonun yüzeyindeki krut kaldırıldığında 'çivi belirtisi' gözlendi (Resim-1a,b). Bu lezyondan alınan biyopsi örneğinin histopatolojik incelemesi pemfigus vulgaris ile uyumluydu (Resim-1c,d). Uzun süreli sistemik steroid ve azatiyopirin kullanım öyküsü olan hastaya ritüksimab tedavisi planlandı. Kullanmakta olduğu azatiyopirin kesildi.

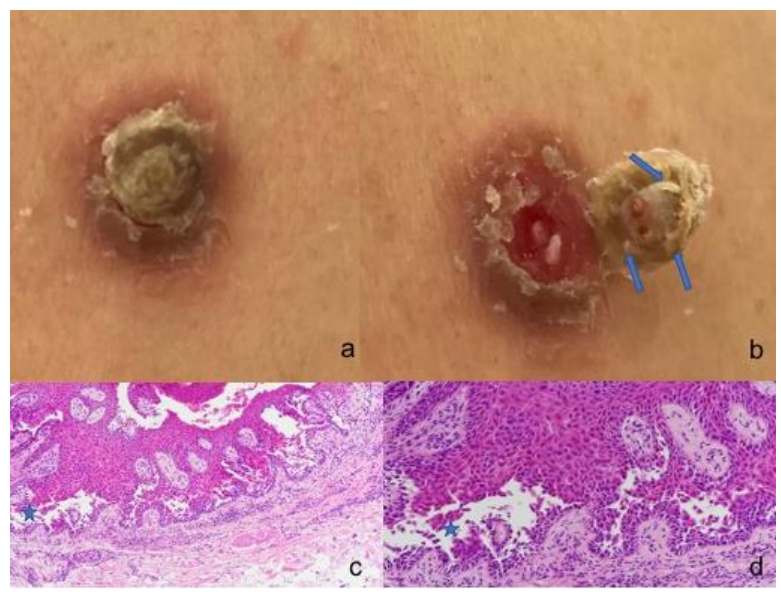

Şekil-1: Periferi eritemli, ortası krutlu lezyon (a), krut kaldırıldı̆ında gözlemlenen çivi belirtisi (b), epidermiste suprabazal ayrıma alanları HEx100 (c), HEx200 (d).

\section{Tartışma}

Pemfigus mukoza ve deride ağrılı ülsere lezyonlarla karakterize otoimmün büllöz bir hastalıktır. Klinik olarak büller ve büllerin açılmasıyla oluşan erozyonlarla seyreden klasik tipi PV olarak adlandırılmaktadır. Bunun dışında yüzeyel krut ve skuamlarla birlikte giden PF, vejetatif kitlelerle giden pemfigus vejetans gibi daha farklı klinik özellikler gösteren ve daha az sıklıkla görülen varyantları da bulunmaktadır.

PV olguları genellikle hem oral mukoza hem deride yerleşen büller ve hemorajik krutlu erozyonlarla karşımıza çıkmaktadır. Az sayıda olguda ise oral mukoza tutulumu olmadan deriye sınırlı az sayıda kalın krutlu lezyonlar görülebilmektedir. Lezyon impetijinize olduğunda bu krut daha da abartılı görünümde olabildiği için ayırıcı tanıya girebilecek diğer dermatolojik hastalıklar açısından güçlük yaratabilmektedir. Böyle lokalize ve belirgin krutlanma ile seyreden pemfigus vakalarının genel PV olguları arasındaki sıklığını belirleyen bir çalışma bulunmamaktadır. Burada sunulan PV olgusu da mukoza tutulumu olmayan ve deriye lokalize, kalın krutla seyreden bir PV olgusudur.

Çivi belirtisi dermatolojik literatürde az çalışılmış bir konudur. Uluslararası düzeyde bakıldığında Prof. Dr. Hulusi Behçet tarafından Fransızca literatürde bu belirtinin 1934 yılında tanımlamış olmasına rağmen (2) PubMed taraması yapıldığında İngilizce literatürde çivi belirtisiyle ilgili ilk yayının 1987 yılında bir PF olgusu olduğu görülmektedir (3). O tarihten sonra yapılmış olan toplam altı yayında belirgin krutla seyreden farklı dermatozlarda çivi belirtisi görülen olgulardan bahsedilmektedir. Çivi belirtisi az çalışılan bir konu olduğu için herhangi bir hastalıkta daha sık görülebildiğine dair bir veri İngilizce literatürde bulunmamaktadır. Türkçe literatürde ise sadece Uzun ve ark.'nın yapmış olduğu çalışma bulunmaktadır. 2002 yılında yapılan bu çalışmada krutlu lezyon nedeniyle başvuran toplam 472 hastada çivi belirtisi varlığı araştırılmıştır. Bunlardan 412'si KL olgusu olup \%10'unda çivi belirtisi pozitif saptanmıştır. Çalışmaya dâhil edilen 52 DLE olgusunun $\% 8$ 'inde, 7 PF olgusunun \%14'ünde çivi belirtisi pozitif saptanmıştır. Bir KBHL olgusunda da çivi belirtisi pozitif bulunmuştur. Bu çalışma serisi çivi belirtisini değerlendiren kapsamlı bir çalışma olması nedeniyle çok kıymetli olmakla beraber hastaların çok büyük bir kısmı KL olduğu ve diğer dermatozlara ait az sayıda olgu olduğu için gerçek bir sıklık kıyaslaması yapılması güçtür (8). Ülkemiz dermatologları Hulusi Behçet tarafından KL'de tanımlanmış olan çivi belirtisinin Türkçe literatürde ve farklı akademik ortamlarda sunulmuş olması nedeniyle çivi belirtisi ile $\mathrm{KL}$ arasındaki ilişkiye daha aşinadır. Bu olgu belirgin krut ve skuam ile seyreden PV lezyonlarında da görülebileceğinin Türk hekimlerine hatırlatılması amacıyla sunulmaktadır. Öte yandan Türkçe ve İngilizce literatürde çivi belirtisi saptanan başka PV olgusu olmaması nedeniyle de önem taşımaktadır.

Çıkar çatışması: Yazarlar çıkar çatışması beyan etmemişlerdir. 


\section{Kaynaklar}

1. Behçet H: Wright çıbanları seririyatında inmal edilmiş iki mühim nokta. TÜRKDERM 1934; 1: 16-22.

2. Behçet $\mathrm{H}$ : Deux points importants et négligés dans le tableau clinique des boutons de Wright. Bull Soc Franc Derm Syph 1934; 41: 97-105.

3. Paramsothy Y, Lawrence CM. 'Tin-tack' sign in localized pemphigus foliaceus. Br J Dermatol. 1987; 116 (1): 127-9.

4. Cox NH, Tapson JS, Farr PM. Lichen planus associated with captopril: a further disorder demonstrating the 'tin-tack' sign. Br J Dermatol. 1989; 120 (2): 319-21.

5. Cowley NC, Lawrence CM. 'Tin-tack' sign in seborrhoeic dermatitis. Br J Dermatol. 1991; 124 (4): 393-4.

6. Thomas RJ, Smith NP, Spittle MF. The 'tin-tack' sign in post-irradiation scalp skin scales. Br J Dermatol. 1992; 126 (1): 90

7. Baba M, Uzun S, Acar MA, Gümürdülü D, Memisoglu HR. 'Tin-tack' sign in a patient with cutaneous B-cell lymphoma. J Eur Acad Dermatol Venereol. 2001; 15 (4): 360-1.

8. Uzun S, Baba M, Alpaslan Acar M, Memişoğlu HR. Hulusi Behçet'in Çivi Belirtisinin Kutanöz Leishmaniasisin Klinik Tanısındaki Değeri. Türkderm, 2002; 36 (1). 